\title{
Principles Governing Personal and Social Relationships Affecting Spiritual Health in the Holy Quran
}

\author{
Narges Shekarbeygi \\ Islamic Studies and Health Sciences Interdisciplinary Research Center, Kermanshah University of Medical Sciences, Kermanshah, \\ Iran
}

Assistant professor of Quran and Hadith Sciences, Department of Islamic Education School of Medicine, Kermanshah University of Medical Sciences, Kermanshah, Iran

Narges.shekarbeygi@kums.ac.ir; shekarbeygi.n@gmail.com

\begin{abstract}
How people can influence others by the way they interact and communicate and be present. It has long been considered by sociologists and scientists such as Gabriel Tard, Jean Mason, etc .; Most of the interpersonal and social relationships of people in society with each other through verbal and non-verbal communication with each other, each of which has a special place in improving individual-social relationships. On the other hand, research shows that spiritual health and its related components have a direct role in improving the health process and people who have paid more attention to this dimension; They have had a healthier life. Familiarity with the effects of these relationships on interpersonal communication processes in issues such as counseling and psychology and often in the diagnosis of mental states, psychologists, and psychiatrists and behavioral disorders is of great importance. Since the Holy Qur'an attaches great importance to human beings and their place in society and interpersonal relations; Referring to the attributes and characteristics that are related to verbal communication, such as situationism, the art of good listening, prioritization, audience knowledge, and the practice of speech, encourages the speaker to engage in this type of behavior so that personal and social relationships are based on the Qur'an. Be healthy and productive.
\end{abstract}

Keyword: Spiritual Health; Personal-Social Communication; Verbal Communication; Holy Quran

\section{Introduction}

Man is a social being. One of the basic tools for improving social life; Having appropriate behaviors is based on the circumstances around him. Human behaviors have a very wide range. In a general division, behaviors can be divided into two types; Identified verbal and non-verbal behaviors. Familiarity with the characteristics of these behaviors and recognizing their nuances will play a very important role in improving interpersonal relationships and the effectiveness of human behavior and speech in the audience and those around. Human behaviors and attention to human happiness have long been the focus of all schools and philosophers. Each of them, from their point of view, has provided solutions for human behavior and social 
life only in a certain dimension. The religion of Islam, based on the verses of the Holy Quran and the hadiths of the Infallibles (AS), has determined the path of human happiness with all its nuances. Expresses the verbal and non-verbal behaviors of human beings accurately and pays attention to all aspects of human existence. He expresses the type of behavior sometimes in the form of a story and sometimes in the form of irony and sometimes directly and so on. It beautifully describes the way of dealing with God, prophets, elders, parents, teachers, and opponents, etc. Paying attention to the verses of the Holy Quran in behaviors will make that behavior fruitful and also maintain the spiritual and mental health of that society. Because human behavior not only affects their lives but also the occurrence of that behavior about others and society, affects their lives. If that behavior is destructive, negative and unhealthy, it will endanger the life, peace and mental health of the community and other people; If society loses its health and peace, it will be impossible for the talents and abilities of individuals to flourish, and many human needs that can be discussed in the light of social life will lose their relevance. The present study seeks to investigate, identify, and introduce several components that play an important role in improving human behavior. Research on persuading and influencing audiences has a long history. The history of these researches goes back to ancient Greece and Rome; But the methods by which a person can influence others by the way he communicates and attends include both verbal and non-verbal methods.

\section{Types of Verbal Methods Based on the Type of Audience}

Sometimes the difference in the type of speech methodology is due to the difference of the audience, and since the speech must be by the needs and type of the audience, these methods of speaking will also be different.

\section{Talking to Parents:}

From the Islamic point of view, the status of parents is very high and their rights over the child are many. The type of behavior and relationship with them is so important that it can change the path of happiness and cruelty. The system of communication with parents is a mixture of politeness, respect, and humility that comes from love and compassion. It is accompanied by gratitude and unconditional gratitude. The following verses show this connection:

(And your Lord has commanded that you shall not serve (any) but Him, and goodness to your parents. If either or both of them reach old age with you, say not to them (so much as) "Ugh" nor chide them, and speak to them a generous word (23) And make yourself submissively gentle to them with compassion, and say: O my Lord! have compassion on them, as they brought me up (when I was) little (24)(Quran 17: 23-24).

Some of the points that emerge from these verses that show the etiquette of talking to parents are:

1- The Holy Quran; To de-harm the conversation with the parents, in a short and meaningful phrase, he forbade saying "F" to the parents. The word F means dirt and contamination. The origin of this word is taken from the fact that whenever a small amount of dirt or ash falls on the body or clothes, a person throws it away when he dies. I This word and its derivatives have been used as a means of unhappiness and hatred, especially for small things (Ragheb Esfahani, 1416, p. 79). 
2- It is forbidden to shout at parents and raise their voices above their own.

3- Observing etiquette and respect when talking to parents, even in case of wrong treatment by them, is one of the duties of children. Children should be patient and tolerant of their parents with thoughtful and respectful speech (Klini, 1401, vol. 2, p. 157).

In the event of a disagreement with the parents, it is necessary to avoid explicit opposition and pretending to disobey them. Hence, the Holy Qur'an emphasizes kindness to parents at all times. (Quran, 31: 15)

4- Expressing humility in speaking, listening, facial expressions, and even eye contact ... are other aspects of etiquette in talking to parents. Imam Sadegh (AS) says the following verse: Do not stare at them except out of love and compassion. (Klini, 1401, vol. 2, p. 167).

\section{Talking to the Child:}

Politeness is the mutual duty of the parties to the dialogue. As the child is obliged to observe the etiquette towards the parents; Parents have the same duty, because they are responsible for educating the child. Imam Ali (AS) says: The right of a child over a father is to discipline him with goodness. (Nahj alBalaghah, Wisdom, 399)

In religious teachings, on the observance of etiquette in calling children (Quran, 11: 42-43 / Quran, 12: 5 / Quran, 37: 102) Interestingly, speech should be consistent with the level of understanding, emotion, and knowledge of the child. As the Holy Prophet (PBUH) says: Whoever has a child, should have a child. (Sadough, 1999, vol. 3, p. 483) and paying attention and value to the personality and opinions of children in conversations is emphasized as an example.

\section{Talking to the Teacher:}

The etiquette of talking and dealing with the teacher is very widespread in religious teachings. An important part of it can be used from the verses related to the story of the meeting of Prophet Moses (PBUH) and Khidr (PBUH) (Quran, 18: 82-60).

1- It is the student who should follow the teacher, and humbly introduces himself as his subject.

2- Getting permission from the teacher to learn science, asking questions, and commenting is one of the student etiquettes.

3- Expressing humility by acknowledging the teacher's knowledge and ignorance.

4- To consider the knowledge and education of the master useful and effective.

5- Expresses his readiness to carry out the teacher's instructions.

6- Ask your questions in a suitable situation.

7- If he knows the master with knowledge and wisdom, he should not object to his works.

8- To reserve the right of reprimand and interrogation for the teacher.

9- If there is an intellectual conflict with the teacher or he does not understand him, he should be separated from him by observing politeness.

10- Listen carefully to the teacher. Imam Sajjad (AS) says: "It is the right of a good teacher to listen to his words." (Saduq, 1378 vol. 2, p. 618) 
11- Do not raise his voice beyond the voice of the master and do not shout. Imam Sajjad (AS) says: "Do not raise your voice louder than the voice of the teacher." (Saduq, 1378 vol. 2, p. 618)

13- Do not talk to others in the presence of the master. (Sadough, 1378 vol. 2, p. 618)

14- It hides the possible shortcomings and shortcomings of the teacher and reveals his advantages. (Sadough, 1999, vol. 2, p. 618)

15- Do not express the opinions of others with the motive of opposing him. Imam Ali (AS) says: "Do not raise the opinions of others too much in opposition to his opinion." (Klini, 1401, vol. 1, p. 37)

\section{Talking to Your Spouse}

Marriage cannot flourish without effective communication. The lives of many couples, due to the lack of necessary communication skills and disregard for the principles and manners of conversation, lead to parallel relationships without intimacy and even destructive. When a relationship becomes dysfunctional or broken, love turns into resentment and anger, resulting in much arguing, embarrassing irony, repeated criticism, or resorting to cold silence. (Bolton, 2002, p. 27) which suppresses the joy and vitality of life.

Therefore, in religious teachings, much emphasis is placed on observing etiquette and establishing effective communication with the spouse. Needless to say, the necessity, the number, and the etiquette of conversation are considered in all stages of life. But this connection must have conditions that include:

\section{A. Relaxing and Hopeful}

In some verses, the Holy Qur'an states that the purpose of marriage is to achieve peace: And one of His signs is that He created mates for you from yourselves that you may find rest in them, and He put between you love and compassion; most surely there are signs in this for a people who reflect (Quran, 30: 21) Accordingly, the conversation at home should be in a way that calms the anxious and disturbed spouse; Give hope to the disappointed and despairing wife; Give the unmotivated and depressed wife willpower and spiritual stability, and make them tired and nervous wife happy and cheerful.

\section{B) Using Supportive Sentences and Appropriate Vocabulary}

The basis of a successful marriage is a wise choice and a loving life, and the stability of the foundations of life depends on the deepening of loving bonds. Be. The important point in cohabitation is that the speaker should be constantly expressed by the couple and the two should support each other because the man always needs trust, acceptance, appreciation, approval, and encouragement. A woman needs attention, love, understanding, and respect.

\section{C-Flawless}

Everyone has more or fewer flaws and shortcomings, the appearance of which can have adverse effects on their relationships. This important thing is more evident in the family environment. Counting each other's flaws and showing off them breaks the sanctities and hurts the veils of modesty and chastity. The Holy Quran, in a beautiful parable of a couple, says: (your wives on the night of the fast; they are an apparel for you and you are an apparel for them) (Quran, 2: 187). 
Dialogue in some times and situations not only does not have the desired effect but also complicates the situation and makes the problems bigger, including; When upset and angry; Because it is very difficult to communicate effectively and effectively when they are upset, dissatisfied and angry. When unpleasant feelings occur, even if they have good intentions, the discussion usually leads to quarrels and fights. (J. Smith, 1379, p. 279).

\section{Verbal Behavior Affecting Spiritual Health:}

\section{To be honest:}

False talk is nothing but deceit, trickery, deception, oppression, and betrayal. The verses of the Holy Qur'an are used, where the place of truthfulness is everywhere, but of course it is very important to note that lying is forbidden but truthfulness is not obligatory, meaning that not every word of truth needs to be said everywhere. (Ansarian, 1371, vol. 10, p. 75) Ethics and honesty are some of the highest human perfections.

\section{Having compassion:}

Speech is the manifestation of existence, and the purer the existence, the more pure and efficient the speech is. Whoever speaks with monotony and compassion, or who advises, guides, or advises a person, his speech is influential, and if his speech is true, it remains. (Dinuri, p. 125).

\section{Politeness and mutual respect:}

Observance of politeness and maintaining the respect of the audience is the first condition for effective, desirable, and stable communication. Disrespect and impunity, even in the way they shout or look, create a mental state for the audience that does not accept the speaker's words and ignites the fire of anger and hatred towards him. Hence, it is necessary to maintain decency and politeness, even where the other party does not adhere to it. This is how Ibrahim (AS) when he was insulted in his respectful logical conversation with his uncle Azar and heard the cry of threat and hatred (Quran, 19: 42-46) Again, he paid homage to her and said politely:(Quran, 19: 47) This shows that in the face of deviant people, the first step is to have a respectful conversation. This is doubly important, especially when talking to people in a higher position or when the speaker is in a strong position. The first step to attracting the affection and love of others is to be polite and respectful towards them. According to a narration: "Destroy the respect between yourself and your brother and leave something of it; Because its disappearance causes shame to disappear. And instead of respect, it is a factor in the stability of friendship." (Klini, 1401, vol. 2, p. 627) Paying attention to others, and appreciating and listening to their words are signs of respect. Infallible leaders (AS) always spoke and behaved with respect and reverence to their audiences.

\section{4- Positive attitude:}

In interpersonal communication, different concepts are created or transformed by the listener, because symbols such as words, by themselves, do not convey the necessary semantic load, but need to be interpreted, and in the interpretive process, factors such as context and conditions of speech, attitudes and the speaker's mental space plays a role. Therefore, the two sides of the relationship always interpret each other (Juliati, 13769, p. 74) and can create positive or negative attitudes and sometimes even the opposite. 
Hence, in religious teachings, with an emphasis on positivism, it is required that in communicating with one's religious brethren, the best interpretation of their words be smoothed out; Amir Momenan Ali (AS) says in this regard: Build the work of your religious brother in the most beautiful way ... and never think badly of your brother's words, while you can find a good justification for it. (Klini, vol. 2, p. 362) The Holy Quran, criticizing negativity (Quran, 24: 11-12) And forbid it (Quran, 49: 12) It depicts the life of the divine prophets who, with positivity, reminded the strengths of their people. (Quran, 11: 78-84 / Quran, 12: 90100)

The prophets used this method to influence it and to establish favorable communication. Negativity sometimes turns into a mental illness in which a person looks at only the negative points of each speech and each speaker and even interprets the positive elements negatively. One of the important origins of this condition is the weakness of faith and trust in God, fear, and dread of everything; A situation that is characteristic of hypocrites according to the Holy Quran. (Quran, 63: 4).

In human relations psychology, it is proven that whatever the audience feels that the speaker is trustworthy and positive, it causes him to look at the speaker positively, and this in turn encourages him to accept the speaker and the message he contains. (Karimi, 1999, p. 85) Always use words that have a positive effect on the attitude and morale of the other party and the audience; It can convince him. The speaker's sentences should be so beautiful and attractive that they both attract the audience's attention and easily convey the speaker's meaning well. Show his positive attitude to the audience. (Robert, 2009, p. 51) If a personal speaker is positive, he can communicate with the audience more easily. He can find out what others want to talk about and find it interesting and interesting; In this case, the speech will be effective. (Jan 1374, p. 40) The emergence of positive and pleasant emotions in dealing with others creates friendships and increases the strength and intensity of previous relationships. (Abbasnejad, 1384, p. 141)

\section{Trust building:}

One of the important factors of good and effective communication and influence in the audience is gaining their trust in the speaker's speech and motivation. There is a direct relationship between increasing trustworthy elements and increasing audience acceptance. The Holy Quran, with an interesting reference to the story of Prophet Ibrahim (AS), has stated this fact. (Quran11: 69-70)

To listen and pay attention to someone, people must trust him, consider him a close, kind, knowledgeable and insightful friend. (Carnegie, 1998, p. 21) One of the factors in the failure of speakers; Fear and lack of self-confidence, enough attention to the subject of speech and expertise, and practice in the content, will undoubtedly strengthen self-confidence. Also, when the speaker's heart and brain are full of a series of meanings and have faith and certainty in his speech, he will undoubtedly affect speech, expression, and trust (both the speaker's self-confidence and the audience's confidence in the speaker's words). (Shariati Sabzevari, 1997, p. 48) Trustworthy elements in speech are:

A) benevolence: The impression of benevolence and compassion of the speaker in the mind of the audience strengthens his trust and as a result, causes the greater impact of speech on his heart and soul. Therefore, the prophets emphasized the goodness and compassion of Hood when inviting and talking. (Quran, 26:135/ Quran, 19: 45-47 / Quran, 23: 30-32/ Quran, 7: 79,62,93). 
He rejected them (Quran, 11: 29/ Quran 25: 57/ Quran, 26: 164, 109, 126/ Quran, 42/23) Speech must be pure. The spirit of the speaker must be benevolent, have a healthy spirit. In the speech, refrain from biting, taking revenge, and eating people's personalities. The divine prophets have been sent for this purpose of propagating the divine mission and benevolence of the people (Quran, 7: 62,67).

Action-based on the spirit of benevolence and love has a special effect and is a very important factor in the popularity of the speaker. Imam Ali (AS) says: Whoever loves people, they will love him. (Amadi, 1361, p. 41) Experts say: Love the audience, people understand that you love them or not? (Carnegie, 1998, p. 156).

B) Avoid self-centeredness: Pride and arrogance in conversation (Quran, 2:106) And ignoring the attitudes of the other party: (Quran, 11: 28), will deprive him of trust in establishing useful and effective communication. Psychologists, sociologists, and psychiatrists all agree that lack of self-centeredness in relationships is a normal criterion and that selfishness and egoism are manifestations of the disease, in the sense that as much as the behavior becomes conventional, Not to the extent that it makes us profitable, our relations with others become normal. (Abbasnejad, 2005, p. 305).

\section{Confidentiality:}

Confidentiality and protection of secrets is a sign of trustworthiness and human wisdom. This important thing, in interpersonal relationships, is manifested in two cases: keeping one's head, keeping others' heads. Because revealing the secret is the weakness of the soul and the weakness of the intellect. Revealing secrets and spreading rumors whose disclosure would be detrimental to oneself or others; It is a great and irreparable plague of the tongue. Disclosure and retelling include discovering a defect and telling a secret because the head is not always a defect. But in many cases, disclosing it offends the believer and is against his interests. Of course, sometimes it will lead to disgrace or financial loss. Disclosure, then, is a kind of betrayal that the whistleblower commits to the secrets and trusts of the people. This is mainly due to the incompetence, hypocrisy, enmity, or gain that lowly people accept. Confidentiality is the key to developing trust and a constructive relationship between the speaker and the audience. Confidentiality is a means of securing and protecting a person's privacy. (Hosseinian, 1385, p. 78)

\section{Good listening art:}

Listening is very important in interpersonal relationships. According to some studies, on average, $45 \%$ of communication time is spent listening (Harji, 1998, p. 215), but few people are good listeners. Because there is a difference between "hearing" and "listening": "Listening" is used to describe that part of the sensory process through which auditory stimuli are received in the auditory system and sent to the brain. But "listening" is a more complex psychological activity that involves understanding, interpreting, and interpreting sensory experiences. (Bolton, 2002, p. 61) Certainly, the Holy Quran does not want to say listen to every speaker, but the speaker must be trusted and worthy; If it is in the normal cases and flow of life, it must be a reliable and truthful speaker, and if it is related to technical matters and requires ijtihad. That person must have ijtihad and expertise in that field. (Mesbah Yazdi, 1388, p. 438) This technique can be very effective in improving relationships and expanding relationships with others to have a successful life. Of course, many behavioral and communication scientists believe that understanding with others is not easy. But to achieve it, a lot of effort must be made. It can be said that most scientists are among the various attributes and various tasks that improve relationships and create spiritual health; Two skills; They need to listen, think, and talk about communication. Most people usually pay attention to what they say and think 
that the sender of the message plays a key role in the communication process. This idea may be based on ancient Greek thought. Because they considered communication to be one-way and transmitter-oriented. Effective listening; It is far more difficult than eloquence. $42 \%$ of the human awakening time is spent listening and $32 \%$ talking. Of course, the second skill is empathy with the audience, which must be accompanied by listening skills. (Farhangi, 1385, p. 207)

First, let the other person speak; Of course, this is not true in all conversations, but in speeches where there are many ambiguities and questions about the audience or speaker, the rule is to allow the other party to begin to speak. When the other party speaks, whether they like it or not, they give information about their positions, motivations, and needs. Of course, it is impossible to speak and listen at the same time. As a rule, a human being who is talking cannot be a good listener at the same time. Listen well first so you can be a good language. (Garshasbi, 1384, p. 43)

\section{Discussion}

The Holy Quran is a mirror and a charter of all the programs that are needed for human life. This heavenly book deals with all aspects of human existence with beauty, elegance, and non-linearity. One of the deep and precise teachings of religious teachings is to pay attention to the behavioral dimension of human beings and to address the moral and behavioral necessities of human beings. One of the human behaviors is verbal behaviors that have a very high status; Because most human communication takes place through speech; On the other hand, many pests are lurking in this divine blessing and God-given tool. The Holy Quran beautifully introduces everyone to the kind of conversation with parents that should always be with compassion, kindness, and finally politeness and respect. It also describes the way of dealing and talking with children, teachers, spouses, etc. as beautifully as possible. Also, the Holy Qur'an and the narrations of the Infallibles (AS) express the attributes and components that strengthen these human behaviors. Traits such as confidentiality, honesty, compassion, positivity, etc., which cause healthy behavior and effective speech; It happens both at the individual level and at the community level. Of course, it is obligatory for all members of society to be aware of non-verbal cues in addition to being familiar with the types of attributes and components that affect the effectiveness of the speech. According to researchers, nonverbal behaviors convey a large amount of information and often messages and emotions are transmitted to the audience through this. Paying attention to these symptoms depends on knowing the types and status of these behaviors. Recognizing non-verbal behaviors and paying attention to spoken points can express the best kind of human behaviors that are in accordance with the complete divine commands and verses of the Holy Quran. These types of behaviors will play an important role in the mental health of the community and the improvement of interpersonal relationships. The results show that comprehensive and holistic care is not limited to physical needs and physical health. Health is achieved when it provides all the dimensions of health. Research shows that based on the existence of various human fields, schools, and theorists with humanistic and divine views ... have introduced several aspects in the field of health. One of the most important aspects of health today is spiritual health. 


\section{References}

The Holy Quran, translated by Makarem Shirazi, Nasser, Qom: Musharraf, first edition, 2008.

Nahj al-Balaghah, translation: Dashti, Mohammad, first edition, Qom: famous, 2000.

Abbasnejad, Mohsen, Quran, Psychology and Educational Sciences, Mashhad, Publishing Institute of Quran Research Foundation and University, First Edition, 2005.

Amadi, Abdolvahed, Gharr al-Kalam wa Dar al-Kalam, translated by Jamal Khansari, researched and edited by Seyyed Jalaluddin Mohaddes Ermoi, Tehran, Tehran University Press, 1982.

Ansarian, Hossein, Islamic mysticism, Isfahan, Nashr-e-Hojjat, 1992.

Bolton, Robert, Psychology, Human Relations (People's Skills), Translator: Hamid Reza Sarabi, Tehran, Roshd Publications, First Edition, 2002.

Carnegie, Dale, Lecture, Translator: Jahangir Afkhami, Tehran, Armaghan Publications, First Edition, 1998, p. 21.

Karimi, Abdolazim, Discourses on Hidden Effects, Traumatic Education, Tehran, Publications of the Association of Parents and Teachers, Fourth Edition, 1999.

Dinuri, Abdullah Ibn Muslim, Ayoun Al-Akhbar, Beirut, Dar Al-Kitab Al-Almiyeh Publications, Bita.

Robert, Rickard, How to Convince Others Translator: Mojgan Qasqaeipour, Tehran, Hamadad Afraz, Omid Farzanegan, Second Edition, 2009.

Farhangi, Ali Akbar, Human Communications, Tehran, Rasa Cultural Services, Tenth Edition, 2006.

Garshasbi, Asghar, The Art and Technique of Negotiation, Tehran, Mohajer Publishing, First Edition, 2005. Harati, Mohammad, Tahf al-Aqool, Qom, Basirati, 1351.

Harji, Owen and Saunders, Christine and Dixon, David, Social Skills in Interpersonal Communication, Translators: Khashayar Beigi, Mehrdad Firooz Bakht, Tehran Roshd, first edition 1998.

Hosseinian, Simin, Ethics in Counseling and Psychology, Tehran, Kamal and Tarbiat Publishing, First Edition, 2006.

Ian, Richard, How to Express Your Content Successfully, translated by Keyvan Spanloo, Tehran, Farabi, first edition, 1995.

J. Smith, Alfred, Communication, and Culture, translated by Mohammad Babaei Ahri, Tehran, Samat Publications, first edition, 2000. 
Juliati, Wood, Interpersonal Communication; Psychology of social interaction, translated by Firoozbakht, Mehrdad, Mahtab Publishing, 2000.

Klini, Muhammad ibn Ya`qub, Al-Kafi, research on Ali Akbar Ghaffari, Beirut: Dar al-Ta'rif, 1401 AH.

Majlisi, Mohammad Baqir, Baharalanvar, Beirut, Dar Al-Haya Al-Tarath Al-Arabi Publications, 1982.

Mesbah Yazdi, Mohammad Taghi, Humanization in the Quran, Imam Khomeini Educational and Research Institute Publications, First Edition, 2009.

Naraghi, Mehdi, Jame Al-Saadat, correction: Mohammad Kalantar, Najaf Al-Ashraf, Najaf, 2004.

Ragheb Isfahani, Mohammad Ibn Hussein, Glossary of the words of the Holy Quran, research of Safwan Adnan Davoodi, Dar al-Alam, Damascus, 1416 AH.

Saduq, Muhammad ibn Ali, from the presence of the jurisprudent, Qom: Teachers Association, 1999.

Shariati Sabzevari, Mohammad Baqer, Principles, and Principles of Speech, Qom, Qom Seminary Islamic Propaganda Office, Second Edition, 1997.

Tabatabai, Mohammad Hussein, Al-Mizan Fi Tafsir Al-Quran, translated by Seyyed Mohammad Baqer Mousavi Hamedani, fifth edition, Qom: Qom Seminary Teachers Association, 1995.

Tusi, Mohammad Ibn Hassan, Tahdhib al-Ahkam, Islamic Library, edited by Ali Akbar Ghafari, Tehran, Sadough Publishing, 1997.

\section{Copyrights}

Copyright for this article is retained by the author(s), with first publication rights granted to the journal.

This is an open-access article distributed under the terms and conditions of the Creative Commons Attribution license (http://creativecommons.org/licenses/by/4.0/). 